\title{
General practitioners' attitudes to child injury prevention in the UK: a national postal questionnaire
}

\author{
Yvonne H Carter, Pauline SA Morgan, Robert J Lancashire
}

\begin{abstract}
Objective-To survey the level of interest and involvement in child injury prevention among general practitioners and their practice teams, and to identify factors associated with current interest.
\end{abstract}

Design-Postal survey of a random sample of United Kingdom (UK) medical practitioners.

Setting-Medical practices throughout the UK.

Subjects-957 general practitioners (50\% of the total sample) who responded to the survey questionnaire.

Outcomes-Answer to questions about role in injury prevention.

Results-Despite a response rate of only $50 \%$, this study is the largest to examine the role of general practitioners in child injury prevention. Seven hundred and twenty five $(\mathbf{7 7 \%})$ of the respondents considered injury prevention to be part of the general practitioner's role, but only 260 $(28 \%)$ felt that they did enough in this area. Time was cited as the most significant limiting factor. Women doctors, rural practitioners, members of the Royal College of General Practitioners, and doctors with previous personal experience of serious accidents all had more positive attitudes to injury prevention as a routine part of their activities $(p<0.05)$. Practices providing first aid training for staff were also associated with an interest in injury prevention. The most appropriate times for offering prevention advice were thought to be during child health surveillance clinics and during treatment of an accident.

General Practice University of Birmingham, The Medical School, Edgbaston,

Birmingham B15 2TT,

UK

YH Carter

Royal Society for the Prevention of

Accidents,

Birmingham, UK

PSA Morgan

Department of Public Health and

Epidemiology,

University of

Birmingham, UK

RJ Lancashire

Correspondence to:

Dr Carter.
Conclusions-Awareness about injury prevention opportunities might be improved by emphasising the roles of individual team members and by better addressing the training needs of the whole team.

(Injury Prevention 1995; 1: 164-168)

Keywords: postal survey, attitudes, reported behaviours, general practitioners.

Unintentional injuries are the leading cause of death in childhood and adolescence in the United Kingdom (UK). A recent white paper, Health of the Nation, ${ }^{1}$ proposes that the preven- tion of accidents should be one of the five key areas to be improved over the next 10 years. The aim is to cut deaths from accidents substantially, particularly among children and the elderly. The document suggests that general practitioners (GPs) and their supporting teams should use consultation time to give safety advice. A variety of professionals, including health visitors and community nurses, form the nuclear primary health care team (PHCT). ${ }^{2}$

The government also bases its strategy on better coordination of the agencies involved; the promotion of injuries as a public health issue; better information; and specific actions related to different types of accidents and related to vulnerable groups. Another recent report, that of the National Association of Health Authorities and the Royal Society for the Prevention of Accidents, Action on Accidents, ${ }^{3}$ could form the basis for developing local, regional, and national strategies in this aspect of prevention. To improve primary care the government's programme ${ }^{4}$ also emphasises that the GP will be expected to take an increased role in health promotion. In support of this expectation the 1990 GP contract ${ }^{5}$ recognised that health promotion and disease prevention are integral parts of the services provided by a family doctor. The Health of the Nation Key Area Handbook also suggests that specific accident prevention activities are the responsibility of primary care teams. ${ }^{6}$ Finally, recent work from America suggests that injury prevention counselling can easily be incorporated into primary care paediatric settings. ${ }^{7}$ In the UK the role of the GP in injury prevention and trauma management has been poorly defined. ${ }^{8-10}$ With this in mind, we aimed to investigate the current level of interest and involvement in injury prevention among a representative national sample of general practitioners. A second aim was to examine attitudes towards injury prevention in primary care and identify factors associated with interest.

\section{Subjects and methods}

A pilot survey of a questionnaire involving 200 GPs in 1993 showed that although the questions were understood and relevant to the purpose of the study, the instrument was too long. An amended questionnaire was than sent to a random, non-stratified national sample of 2000 GPs. This sample was selected using a computerised list provided by the British Medical Association of members and nonmembers. The survey proper took place between November 1993 and January 1994. A 
short covering letter explaining the purpose of the study was included, along with a free post reply envelope. A second questionnaire was sent to non-respondents after six weeks. A final mailing to a sample of 400 persistent nonresponders took place in March 1994.

The questionnaire, containing nine pages of both open and closed questions, was divided into two sections. The first covered the PHCT's current perceived role in injury prevention, while the second asked for demographic and practice details - for example, practice size, location, staff and services offered; age, sex, year and country of qualification, and postgraduate qualifications. Various aspects of trauma management and injury prevention were also explored.

Results were analysed using the Statistical Package for the Social Sciences (SPSS-PC+). Significance of associations were calculated using the $\chi^{2}$. Free text responses were subjected to qualitative examination (modified content analysis), to elicit themes related to accident treatment and prevention.

\section{Results}

PERSONAL AND PRACTICE CHARACTERISTICS In the UK there are 33480 general practitioners (including assistants and trainees). ${ }^{11} \mathrm{~A}$ sample of $6 \%$ was agreed for England, Wales, Scotland, and Northern Ireland. Of the 2000 practitioners mailed, 1037 (52\%) questionnaires were returned after the completion of the third mailing. Eighty questionnaires were excluded from the analysis because of death, retirement, change of job, change of address, or completion by the practice nurse - giving a final response rate of $50 \%$.

The personal and practice characteristics of the respondents are given in table 1 . A comparison between national figures and study respondents showed similar patterns in sex, partnership size, and practice area, but the sample over represented respondents under 40 years of age. ${ }^{11}$ The mean age of respondents was 42.6 years; the male to female ratio was $2 \cdot 4: 1$; the mean year of qualification was $1975 ; 107$ doctors $(11 \%)$ qualified overseas; and $80(9 \%)$ practised alone. The average consultation time was 8.7 minutes. At the time of the survey 361

Table 1 Personal and practice characteristics of respondents $(\boldsymbol{n}=957)$ compared with national figures

\begin{tabular}{lcc}
\hline Characteristic (responses to topic) & No $(\%)$ & National $(\%)$ \\
\hline Principal $(\mathrm{n}=951)$ & $850(89)$ & $(93)$ \\
Male $(\mathrm{n}=954)$ & $670(70)$ & $(71)$ \\
Aged under $40(\mathrm{n}=870)$ & $381(44)$ & $(38)$ \\
Single handed $(\mathrm{n}=915)$ & $80(9)$ & $(10)$ \\
Fund holding or due to become so $(\mathrm{n}=946)$ & $361(38)$ & $(34)$ \\
Dispensing & $92(10)$ & $(13)$ \\
Rural $(\mathrm{n}=942)$ & $170(42)$ & $(43)$ \\
Deprivation payments received $(\mathrm{n}=900)$ & $352(39)$ & $(45)$ \\
Qualified UK $(\mathrm{n}=949)$ & $842(89)$ & $\star$ \\
MRCGP & $433(45)$ & $\star$ \\
DCH/DCCH & $162(17)$ & $\star$ \\
Training practice $(\mathrm{n}=941)$ & $387(41)$ & $\star$ \\
Health centre premises & $286(30)$ & $\star$ \\
Computerised (n=948) & $870(92)$ & $\star$ \\
District nurse practice based & $640(67)$ & $\star$ \\
Health visitor practice based & $699(73)$ & $\star$ \\
Child health surveillance clinic & $777(83)$ & $\star$ \\
\hline
\end{tabular}

^Figures not available. DCH/DCCH $=$ Diploma in Child Health/Diploma in Community Child Health. practices $(38 \%)$ were 'fund holding' (an arrangement whereby practices have the opportunity to purchase health services for their patients within a limited budget) or due to become so, and 286 doctors $(30 \%)$ practised from a health centre. Responding principals had an average list size of 1961 (similar to the national average of 1838$)$ ). Over $90 \%$ of practices were computerised, but only 305 doctors $(35 \%)$ said they recorded all significant events, including accidents, on computer. A majority of responding practices $763(85 \%)$ were receiving band 3 health promotion payments, and 113 $(12 \%)$ respondents support the inclusion of accident data in a future banding structure. (Banding was introduced as a financial incentive for practitioners to reduce the incidence of coronary heart disease and stroke among at risk patients.) Two thirds $(647 / 68 \%$ ) of responding practices were located less than five miles from an accident and emergency department. Seven hundred and seventy seven respondents $(83 \%)$ stated they regularly ran a child health surveillance clinic, but when the practice ran such a clinic, only $49 \%$ of the responding doctors took part personally.

\section{PREVENTION AND TREATMENT}

As shown in table 2, $725(77 \%)$ respondents considered injury prevention to be part of their role. However, only $260(28 \%)$ felt that they did enough accident prevention work. Characteristics with high statistically significant relationships with positive attitudes towards prevention included membership of the Royal College of General Practitioners (MRCGP) and previous personal experience of treating a serious accident. No significant associations were found between whether the physician considered injury prevention to be part of his or her role and whether he or she practised alone, worked in a training practice, a deprived area, or trained overseas. Lack of time was cited as the most significant limiting factor inhibiting more prevention work by 233 doctors $(36 \%)$, followed by lack of knowledge $40(10 \%)$, and insufficient resources $23(6 \%)$.

Well over half the respondents gave advice to parents $621(65 \%)$ after a childhood injury. Safety equipment was recommended by 498 $(53 \%)$ respondents. Stair gates, fireguards, and car seats were the items most frequently suggested. However, only $131(14 \%)$ doctors would try to dissuade parents from buying specific items of nursery equipment; most commonly, baby walkers, small toys, or pillows/quilts.

The most appropriate times to give prevention advice to parents were considered to be during child health surveillance clinics and when treating an injury. Respondents rarely gave leaflets on safety to parents of children under 5 years $(9 \%)$ or to teenagers $(1 \%)$ and only a minority of GPs (15\%) having access to parent held records use them as an opportunity to discuss safety. A somewhat larger proportion, 280 respondents $(30 \%)$, frequently discuss particular safety issues with the health visitor.

The type of services available for the treat- 
ment of injuries are listed in table 3. Most practices offer a wide range of treatment for minor trauma. However, only $206(22 \%)$ communicated the availability of such services to patients in a practice leaflet.

Table 2 Responses to injury prevention questions according to doctor/practice characteristics (opinions expressed as a \% with denominator in brackets)

\begin{tabular}{|c|c|c|c|}
\hline Doctor/practice characteristic & Yes & No & $\chi^{2}$ \\
\hline $\begin{array}{l}\text { Injury prevention as role of GP } \\
\text { MRCGP } \\
\text { Experience of serious accident } \\
\text { Rural } \\
\text { Male doctor } \\
\text { First aid training for staff }\end{array}$ & $\begin{array}{l}49(725) \\
30(712) \\
20(713) \\
68(725) \\
52(715)\end{array}$ & $\begin{array}{l}35(221) \\
18(213) \\
11(218) \\
77(218) \\
42(219)\end{array}$ & $\begin{array}{l}13 \cdot 1^{\star \star \star} \\
11 \cdot 0^{\star \star \star} \\
9 \cdot 2^{\star \star} \\
7 \cdot 3^{\star \star} \\
5 \cdot 2^{\star}\end{array}$ \\
\hline $\begin{array}{l}\text { Advice given to parents after inju } \\
\text { Experience of serious accident } \\
\text { Health promotion display }\end{array}$ & $\begin{array}{l}30(611) \\
81(614)\end{array}$ & $\begin{array}{l}22(318) \\
74(324)\end{array}$ & $\begin{array}{l}7 \cdot 6^{\star \star} \\
5 \cdot 6^{\star}\end{array}$ \\
\hline $\begin{array}{l}\text { Advice given at } \mathrm{CHS} \text { clinic } \\
\text { Doctors under } 40 \text { years old } \\
\text { UK trained } \\
\text { Deprivation payments }\end{array}$ & $\begin{array}{l}52(592) \\
93(630) \\
40(595)\end{array}$ & $\begin{array}{l}38(101) \\
86(113) \\
29(110)\end{array}$ & $\begin{array}{l}6 \cdot 1^{\star} \\
4 \cdot 7^{\star} \\
4 \cdot 5^{\star}\end{array}$ \\
\hline $\begin{array}{l}\text { Advice given during routine surge } \\
\text { Doctors under } 40 \text { years old } \\
\text { Single handed } \\
\text { Rural practice }\end{array}$ & $\begin{array}{l}38(226) \\
11(240) \\
24(246)\end{array}$ & $\begin{array}{r}55(466) \\
6(480) \\
16(488)\end{array}$ & $\begin{array}{l}15 \cdot 8^{\star \star} \\
5 \cdot 1^{\star} \\
5 \cdot 1^{\star}\end{array}$ \\
\hline $\begin{array}{l}\text { Safety equipment recommended } \\
\text { Experience of serious accident } \\
\text { Paediatric hospital post } \\
\text { DCH } \\
\text { Male doctor } \\
\text { MRCGP } \\
\text { Rural } \\
\text { Doctor under } 40 \text { years old } \\
\text { Health promotion display } \\
\text { First aid for staff }\end{array}$ & $\begin{array}{l}35(488) \\
65(498) \\
21(498) \\
66(498) \\
50(498) \\
21(490) \\
48(453) \\
82(494) \\
54(493)\end{array}$ & $\begin{array}{l}19(425) \\
53(436) \\
13(436) \\
75(433) \\
41(436) \\
14(430) \\
39(395) \\
76(428) \\
47(429)\end{array}$ & $\begin{array}{l}28 \cdot 2^{\star \star \star} \\
14 \cdot 5^{\star \star \star} \\
10 \cdot 7^{\star \star} \\
7 \cdot 8^{\star \star} \\
7 \cdot 6^{\star \star} \\
6 \cdot 7^{\star \star} \\
5 \cdot 7^{\star} \\
5 \cdot 1^{\star} \\
3 \cdot 9^{\star}\end{array}$ \\
\hline $\begin{array}{l}\text { Leaflet giving available trauma se } \\
\text { Five miles or less to A\&E } \\
\text { Experience of serious accident } \\
\text { DCH } \\
\text { MRCGP } \\
\text { Rural practice } \\
\text { Deprivation payments } \\
\text { First aid for staff }\end{array}$ & $\begin{array}{l}58(206) \\
37(201) \\
24(206) \\
54(206) \\
24(203) \\
33(199) \\
57(203)\end{array}$ & $\begin{array}{l}71(737) \\
25(726) \\
15(740) \\
43(740) \\
16(732) \\
41(698) \\
49(734)\end{array}$ & $\begin{array}{l}10 \cdot 9^{\star \star \star} \\
10 \cdot 9^{\star \star \star} \\
8 \cdot 5^{\star \star} \\
7 \cdot 5^{\star \star} \\
5 \cdot 2^{\star} \\
4 \cdot 1^{\star} \\
3 \cdot 9^{\star}\end{array}$ \\
\hline $\begin{array}{l}\text { Discuss safety with health visitor } \\
\text { First aid for staff } \\
\text { Experience of serious accident } \\
\text { MRCGP } \\
\text { Health promotion display }\end{array}$ & $\begin{array}{l}60(277) \\
35(275) \\
53(280) \\
84(279)\end{array}$ & $\begin{array}{l}45(648) \\
25(647) \\
43(653) \\
76(645)\end{array}$ & $\begin{array}{l}15 \cdot 1^{\star \star \star} \\
9 \cdot 2^{\star \star} \\
7 \cdot 7^{\star \star} \\
6 \cdot 0^{\star}\end{array}$ \\
\hline $\begin{array}{l}\text { Discuss safety with PHCT } \\
\text { Experience of serious accident } \\
\text { First aid for staff } \\
\text { Fund holder }\end{array}$ & $\begin{array}{l}37(172) \\
59(174) \\
46(175)\end{array}$ & $\begin{array}{l}26(737) \\
47(738) \\
36(737)\end{array}$ & $\begin{array}{l}9 \cdot 0^{\star \star} \\
6 \cdot 6^{\star} \\
5 \cdot 3^{\star}\end{array}$ \\
\hline $\begin{array}{l}\text { Keep accident log book in surger } \\
\text { First aid training for staff } \\
\text { Attached district nurse } \\
\text { Single handed } \\
\text { Fund holder } \\
\text { MRCGP } \\
\text { Training practice }\end{array}$ & $\begin{array}{l}58(551) \\
74(553) \\
5(532) \\
44(553) \\
49(553) \\
44(549)\end{array}$ & $\begin{array}{l}38(387) \\
58(393) \\
14(376) \\
30(386) \\
40(393) \\
36(386)\end{array}$ & $\begin{array}{l}36 \cdot 6^{\star \star \star} \\
25 \cdot 8^{\star \star \star} \\
19 \cdot 1^{\star \star \star} \\
16 \cdot 4^{\star \star \star} \\
7 \cdot 8^{\star \star} \\
5 \cdot 9^{\star}\end{array}$ \\
\hline $\begin{array}{l}\text { First aid training for staff } \\
\text { Attached district nurse } \\
\text { Deprivation payments } \\
\text { Fund holder }\end{array}$ & $\begin{array}{l}74(472) \\
34(453) \\
42(472)\end{array}$ & $\begin{array}{l}60(473) \\
44(439) \\
34(468)\end{array}$ & $\begin{array}{l}24 \cdot 0^{\star \star \star} \\
8 \cdot 9^{\star \star} \\
6 \cdot 3^{\star \star}\end{array}$ \\
\hline
\end{tabular}

${ }^{\star} \mathrm{p}<0.05 ;{ }^{\star \star} \mathrm{p}<0.01 ;{ }^{\star \star} \mathrm{p}<0.001$. Explanation of table: in row one of the table there were 725 doctors who thought injury prevention was a role of the GP of which $49 \%$ ( 355 cases) had a MRCGP qualification as opposed to 370 who did not. There were 221 doctors who thought injury prevention was not their role, 35\% (77) possessed an MRCGP, and 144 did not. A\&E = accident and emergency department; CHS $=$ child health surveillance; $\mathrm{DCH}=$ Diploma in Child Health

Table 3 Type of injury treatment available in practices $(n=957)$

\begin{tabular}{lcccc}
\hline \multicolumn{3}{c}{ Provided by (\%) } & \\
\cline { 2 - 4 } Treatment (responses to topic) & GP only & $\begin{array}{l}\text { Practice nurse } \\
\text { only }\end{array}$ & Both & Total \\
\hline Cleansing and dressing wounds & $25(3)$ & $485(51)$ & $428(45)$ & $938(98)$ \\
Suturing a laceration & $653(68)$ & $24(3)$ & $135(14)$ & $812(85)$ \\
Steristrips to a cut & $62(6)$ & $354(37)$ & $506(53)$ & $922(96)$ \\
Removal of a foreign body & $570(60)$ & $25(3)$ & $239(25)$ & $834(87)$ \\
Bruises/strains & $193(20)$ & $216(26)$ & $510(53)$ & $919(96)$ \\
Minor burns/scalds & $80(8)$ & $326(34)$ & $519(54)$ & $925(97)$ \\
Minor head injury & $662(69)$ & $25(3)$ & $189(20)$ & $876(92)$ \\
Tetanus vaccine & $47(5)$ & $378(39)$ & $518(54)$ & $943(99)$ \\
Minor fractures & $283(30)$ & $7(1)$ & $45(5)$ & $335(35)$ \\
\hline
\end{tabular}

NOTIFICATION

Ninety per cent, 853 doctors, routinely receive notification when a child is admitted to hospital after an accident and most $(84 \%)$ are notified when a child was seen in an accident and emergency department. However, only 172 $(18 \%)$ doctors knew of local paediatric liaison health visitors. All children under 5 years of age who are treated at hospital after an accident should have that visit notified to their own health visitor, often by a liaison health visitor who is responsible for improving information flow between primary and secondary care. ${ }^{12}$

\section{AWARENESS AND TRAINING}

A minority knew of any local child accident prevention groups ( $4 \%$ ) and only 18 respondents $(2 \%)$ acknowledged that either they or another member of their PHCT belonged to any such group. Only 17 respondents $(2 \%)$ had ever considered 'accidents' as a topic for audit and only $92(10 \%)$ had personally attended a course or lecture on injury prevention in the last two years. A larger number (149/16\%), however, reported that members of their PHCT had done so recently. Doctors from fund holding practices were more likely to have attended a recent lecture on accident prevention $(p<0.05)$. Ninety nine doctors had completed BASICS (British Association for Immediate Care Scheme) training. GPs with such training provide cover at serious road accidents and have their own monitoring scheme for recording data about injuries seen.

\section{SAFETY AT THE SURGERY}

An injury log book was kept by 553 (59\%) respondents. The majority of practices 744 $(79 \%)$ had a health promotion display in the waiting room, but only $264(34 \%)$ featured injury prevention on the display during the last year.

\section{PREVIOUS EXPERIENCE OF SERIOUS} ACCIDENTS

Two hundred and fifty nine respondents $(28 \%)$ stated that they had previous professional experience of serious or fatal injuries that had made an impression on their current practice. Examples included road traffic accidents, burns, falls, drowning, and farm accidents.

\section{COMMENTS ON INJURY PREVENTION IN} PRIMARY CARE

Over 200 free text responses were subjected to qualitative examination, eliciting themes related to improvement in practice and conditions. The six most commonly listed themes were: (1) need for more time and resources; (2) need to view accident prevention as a public health issue; (3) need to delegate responsibility within the team; (4) need for more training; (5) need to raise awareness of the importance of injury prevention in primary care; and (6) need to implement innovative ideas.

\section{Discussion}

The scope for injury prevention within the primary care setting is enormous, particularly 
if it is incorporated into existing activities because it is evident that time is a critically important limiting factor. Better training is needed but this is an area that is currently being addressed. ${ }^{1314}$ However, the other obstacles identified in the free text responses remain as barriers to be overcome if successful injury prevention is to take place in primary care.

Previous UK studies have aimed to assess the role of family doctors, ${ }^{8-10}$ paediatricians, ${ }^{15}$ health visitors, ${ }^{121617}$ and teachers ${ }^{18}$ in the prevention and treatment of childhood accidents. The key issue that arises from this and previous work is whose role is it? The debate about the relative roles of education, environmental modification, and legislation in child injury prevention continues, ${ }^{19}{ }^{20}$ but there is agreement that there is a need for better designed evaluation studies. ${ }^{21}$ However, a recent literature review by Bass et al was used to support the recommendation of the American Academy of Pediatrics (AAP) to include injury prevention counselling as part of routine health provision. The AAP has endorsed a detailed set of guidelines and materials (TIPP) to help physicians provide such counselling. ${ }^{22}$

\section{WHEN TO GIVE ADVICE}

Child health surveillance clinics or during the treatment of an injury were considered the most appropriate times to give prevention advice. This is consistent with the suggestions made in a recent discussion paper..$^{10}$ Our results suggest, however, that communication between GP and health visitor on safety issues could be improved. Health visitors also see families in their own homes to offer support after an accident. Colver $e t$ al found that health visitors giving specific attention to accident prevention can influence the way that families behave - for example, with regard to the installation of safety equipment. ${ }^{23}$

\section{FIRST AID TRAINING}

A recent study of all deaths from accidental injury reported to the coroner for North Staffordshire between 1987 and 1990 has suggested that death was potentially preventable in at least $39 \%$ among those who died before reaching hospital. ${ }^{24}$ The authors recommend that training in first aid should be more readily available, including courses for patients. In rural areas it is also important that GPs themselves have update training in the management of trauma; a number of respondents in the survey belonged to immediate care schemes such as BASICS. A discussion paper on the role of the PHCT in preventing accidents to children suggests including teaching first aid. ${ }^{10}$

\section{DATA COLLECTION}

Prospective data collection about injuries is easier than record searching and such data are likely to be more accurate. ${ }^{25}$ However, the number of practices prospectively recording this information onto a computer was disappointing. Despite the high standard of notifications of patient injury details to practices, the level of practice-based audit activity in this area was very low. The number of respondents who made use of personal child health records in injury prevention work was also surprisingly low despite the recommendations of a recent report from the Audit Commission. ${ }^{26}$

The most important limitation of this study is the response rate, which was likely to have been influenced by the current low morale in general practice and the increased administrative workload in the $\mathrm{UK} .{ }^{27}$ Although postal surveys typically have a low response rate, ${ }^{28}$ in this study the rate poses a special concern. Practitioners who already recognise the importance of injury prevention may have been more motivated to reply and are, therefore, over represented in the sample. The characteristics of the respondents, however, are similar to national figures. Furthermore, the proportion who felt that they were doing 'enough' accident prevention work was similar to that found in a previous survey $(23 \%))^{9}$ Finally, it is reassuring that those who replied to the third mailing were no diferent to the earlier responders with respect to age, sex, practice size, or general attitudes to injury prevention.

\section{IMPLICATIONS FOR PREVENTION}

This survey reveals that child injury prevention has failed to achieve widespread support in the UK primary care setting. It is practised to a varying extent by a minority of enthusiastic practitioners, and thus probably fails to reach those children and their families who would benefit from it most. A well defined injury prevention role for both GPs and health visitors has yet to be established. Prevention advice tends to be offered opportunistically and sporadically, rather than in a structured age specific manner that could take advantage of regular contact with families during child health surveillance clinics. Material aimed at educating parents about safety also seems poorly used. In general, it appears that at present, GPs do not discuss safety issues with health visitors or other professionals in a way that makes maximum use of all the skills in the primary care team.

Nevertheless, the subject of childhood injuries and their prevention is of sufficient importance to be of interest to everyone in primary care. It is possible that injury prevention will receive a higher profile in the UK in the future, as major system changes continue to emerge.

We thank all doctors who participated in the study. We also appreciate the assistance given by Susan Jowett particularly for transcribing the many open comments. Financial support for the study was given by the Department of Health, London and Dr Kathie Binysh has shown particular interest. This paper is part of a larger report on accident prevention in primary care published by the Royal Society for the Prevention of Accidents.

1 Secretary of State for Health. The health of the nation: a strategy for health in England. London: HMSO, 1992 (CM 1986).

2 Department of Health Management Executive. New world, new opportunities: nursing in primary health care. London: Department of Health, 1993. 
3 National Association of Health Authories/Royal Society for the Prevention of Accidents. Action on accidents: the unique role of the health service. Report of a NAHA/ RoSPA Strategy Group. Birmingham: NAHA/RoSPA, 1990.

4 Department of Health. Promoting better health - the government's programme for improving primary health care. ment's programme for improving
London: HMSO, 1987 (CM249).

5 Department of Health and the Welsh office. General practice in the National Health Service. A new contract. London: HMSO, 1989.

6 Department of Health. The health of the nation. Key area handbook: accidents. London: Department of Health, 1993.

7 Bass JL, Christoffel KK, Widome M, et al. Childhood injury prevention counselling in primary care settings: a critica review of the literature. Pediatrics 1993; 92: 544-50.

$8 \mathrm{Greig} \mathrm{T}$. The GP's role in child accident prevention. Practitioner 1987; 231: 1612-6.

9 Carter YH, Jones PW. General practitioners' beliefs about their role in the prevention and treatment of accidents their role in the prevention and treatment of accidents
involving children. Br $₹$ Gen Pract 1993; 43: 463-5.

10 Kendrick D. Role of the primary health care team in preventing accidents to children. Br f Gen Pract 1994; 44: $372-5$.

11 Office of Health Economics. Compendium of health statistics. 8th Ed. London: Office of Health Economics, 1992.

12 Laidman $\mathrm{P}$. Health visiting and preventing accidents to children. Research report No 12. London: Health Education Authority, 1987.

13 Health Education authority. Preventing accidents to children: a training resource for health visitors. London: Child Accident Prevention Trust, Health Education Authority, 1991.

14 Carter YH, Kenkre JE. Accidents will happen, won't they? A training resource for members of the primary health care training resource for members of the primary health care team. Shaftes 1994.
vies
15 Jackson RH. The doctor's role in the prevention of accidents. Arch Dis Child 1988; 63: 235-7.

16 Carter YH, Bannon MJ, Jones PW. The role of the health visitor in child accident prevention - a survey among health visitors in North Staffordshire. Health Visitor 1992; 65: 115-7.

17 Levene S. Accident prevention: the health visitor's role. Health Visitor 1992; 65: 340-1.

18 Carter YH, Bannon MJ, Jones PW. The role of the teacher in child accident prevention. F Public Health Med 1994; 16 23-8.

19 Pless IB. Accident prevention. BMF 1991; 303: 462-4.

20 Sibert JR. Accidents to children: the doctor's role. Education or environmental change? Arch Dis Child 1991; 66: $890-3$.

21 Towner E, Dowswell T, Jarvis S. Reducing childhood accidents. The effectiveness of health promotion interventions: a literature review. London: Health Education Authority, 1993.

22 American Academy of Pediatrics, Committee on Accident and Poison Prevention. Implementing safety counselling in affice practice. Elk Grove Village, IL: American Academy office practice. Elk G
of Pediatrics, 1990.

23 Colver AF, Hutchinson PJ, Judson EC. Promoting children's home safety. $B M \mathcal{F}$ 1982; 285: 1177-80.

24 Hussain LM, Redmond AD. Are pre-hospital deaths from accidental injury preventable. $B M \mathcal{F} 1994 ; 308: 1077-80$.

25 Agass M, Mant D, Fuller A, et al. Childhood accidents: a practice survey using general practitioners' records and parental reports. Br F Gen Pract 1990; 40: 202-5.

26 Audit Commission. Seen but not heard. Co-ordinating community child health and social services for chileren in need. London: HMSO, 1994.

27 Hannay D, Usherwood T, Platts M. General practitioner workload before and after the new contract. $B M \mathcal{F} 1992$; 304: $615-8$.

28 Moser CA, Kalton G. Survey methods in social investigation. London: Heinemann Educational Books, 1977.

\section{Nineteen injured in school bus crash}

Dewberry, Alberta - At least 19 people were injured when a school bus carrying as many as $\mathbf{4 0}$ children flipped on a highway in east central Alberta. The bus was carrying grade 4 and 5 students on a field trip. Frank Molineux and his wife, Mildred, were two of the first people on the scene. The couple, who are both school bus drivers themselves, assisted some of the children.

Details of the accident were sketchy. 'I understand (the bus) caught the shoulder', said RCMP Sergeant Peter Calvert. 'It went down on its side'.

Editors note: Although this is an excerpt from a newspaper article, the original included no reference to the issue of seat belts in school buses, or to driver training. 